SOCIAL HOUSING IN A COMPETITIVE CITY: EXPLORING THE EVOLUTION AND IMPACTS OF CHANGES IN TORONTO'S SOCIAL HOUSING SYSTEM

\author{
by
}

Vanessa Goettler, BA, University of Guelph, 2004, MA, York University, 2010

\author{
A Major Research Paper \\ presented to Ryerson University \\ in partial fulfillment of the requirements for the degree of \\ Master of Arts \\ in the Program of \\ Immigration and Settlement Studies
}

Toronto, Ontario, Canada, 2010

(C) Vanessa Goettler 2010 
I hereby declare that I am the sole author of this major research paper.

I authorize Ryerson University to lend this paper to other institutions or individuals for the purpose of scholarly research.

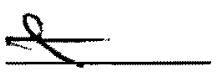

I further authorize Ryerson University to reproduce this paper by photocopying or by other means, in total or in part, at the request of other institutions or individuals for the purpose of scholarly research.

$\vdots$

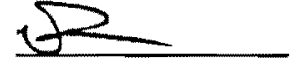




\title{
SOCIAL HOUSING IN A COMPETITIVE CITY: EXPLORING THE EVOLUTION AND IMPACTS OF CHANGES IN TORONTO'S SOCIAL HOUSING SYSTEM
}

\author{
Vanessa Goettler \\ Master of Arts, 2010 \\ Immigration and Settlement Studies \\ Ryerson University
}

\section{ABSTRACT}

This paper seeks to explore the evolution of social housing policy in Toronto as well as provide insight into new "revitalization" initiatives. After identifying key trends in social housing, it compares these insights with the opinions expressed in interviews with key informants in Toronto's housing sector. The implications of this research reveal several important findings. First, in regard to the supply of social housing, it is clear that Toronto is in the midst of a housing crisis. Secondly, despite significant research that casts doubts on the proposed benefits of new "revitalization" schemes, key informants in the sector appear to have accepted the current agenda of the social housing sector. The entrenchment of such opinions, it is argued, marks a clear change from past priorities in social housing and also contributes to the overshadowing of the dismantling of the social housing sector at a time when it is most needed.

Key words: social housing, neoliberalism, revitalization, Toronto, Canada 


\section{Acknowledgements}

I want to acknowledge the support and encouragement of everyone who has helped me throughout this past year. In particular, I wish to extend my sincere appreciation to:

My supervisor, Dr. Sutama Ghosh, for her patience, guidance and encouragement throughout the research and writing process.

Dr. Myer Siemiatycki, for not only his help as a second reader, but also the invaluable support and guidance that he has offered me throughout my time at Ryerson.

The research participants themselves - thank you for sharing your time and opinions with me.

Finally, to my family and friends, especially John, thank you for your love and support. 


\section{TABLE OF CONTENTS}

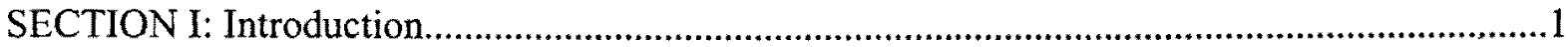

SECTION II: A Brief Review of Social Housing Policy and "Revitalization/Social Mix"

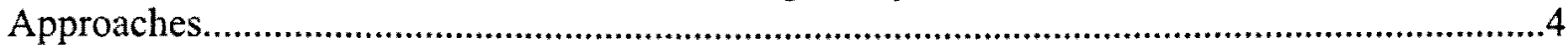

The Origins of Canadian Social Housing Policy (1950s-1970s)........................................4

Neoliberalism and the Dismantling of Canada's Social Housing Sector (1980/90s -

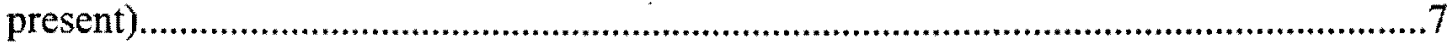

Spatial Dimensions of Poverty and Ethnicity in Social Housing.....................................10

"Social Mix" and Social Housing in a Neoliberal Era....................................................12

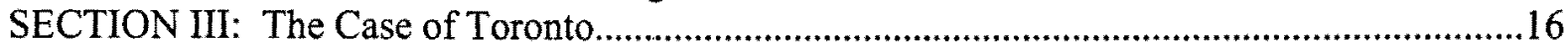

Revitalization/Social Mix Initiatives at Toronto Community Housing............................18

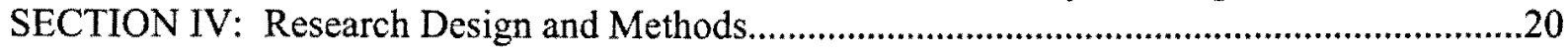

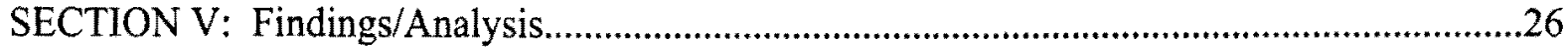

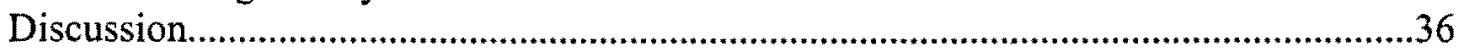

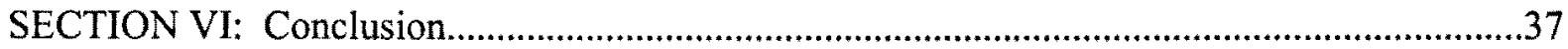

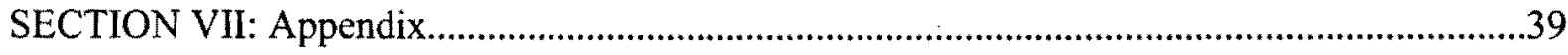

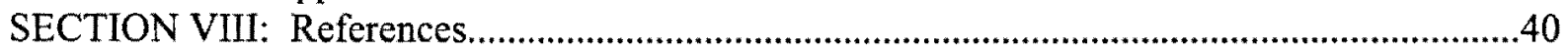




\section{Introduction}

Acknowledged as an important component of social inclusion, the housing situation of low income earners in Toronto has drawn renewed attention in recent years. Behind the city's marketing of itself as a competitive, "global city" and concomitant efforts to attract increasing amounts of global capital, an increasingly neoliberal policy agenda has often conflicted with the reality of many people who reside here. This is born out by current research that demonstrates that increasing numbers of persons are struggling to find housing that is adequate, suitable, and affordable in this city, particularly those of visible minority and immigrant background (CMHC 2006, Wayland 2007). At the socio-spatial level, the impact of such developments combined with the evolution of housing policy in the last twenty years has been credited with creating new urban divides. While research has discouraged the labelling of low income areas as "ghettos" characteristic of those found in the United States (Murdie \& Teixera 2003, Walks \& Bourne 2006), the city's status as a "divided city" (Hulchanski 2007) marks a distinct contrast between its motto of "diversity our strength" and the lived experiences of many Torontonians.

Looking closer at the housing situation of many low income earners in Toronto reveals a troubling picture. Despite the fact that access to adequate housing is internationally recognized as a human right ${ }^{1}$, recent developments in housing policy have shifted away from an earlier consensus on the need for intervention in the housing market. Social housing ${ }^{2}$, a strategy once conceived as an important and accepted safety net in addressing the housing needs of low income earners, has today devolved into a highly neoliberalized sector, ill equipped to respond to

\footnotetext{
${ }^{1}$ According to the United Nations, "All citizens of all States, poor as they may be, have a right to expect their Governments to be concerned about their shelter needs, and to accept a fundamental obligation to protect and improve houses and neighbourhoods, rather than damage or destroy them" (Fact Sheet 21).

.$^{2}$ As Wolfe (1998) points out, "The term social housing is used in Canada to describe all forms of publicly assisted housing: public, non-profit and co-op" (p.123).
} 
the needs of those who depend upon it, many of whom in Toronto are of immigrant background (Wayland 2007, p.25). While not alone in suffering from such a change in orientation, Toronto serves as a strong case study for the effects of changes in social housing policy, demonstrating the implications of a neoliberal governance strategy that has progressively squeezed the sector of its original social welfare orientation. While waiting lists for existing, poorly funded social housing structures continue to grow, new "social mix" "revitalization" strategies have emerged as an attempt to add needed revenue to the sector and cure problems of concentrated poverty. Critics of such developments however, point to an alternative agenda on the part of planners to gentrify social housing and marginalize low income tenant populations.

The destruction of older post-war era public housing developments and their replacement with new "socially mixed" communities is not uncommon among contemporary cities within Western Europe and the United States. Indeed, some authors have suggested that such developments now represent the "go to restructuring approach for public housing agencies across the developed world" (August \& Walks forthcoming). In the Toronto context, the creation of new "socially mixed" communities in once solely rent-geared-to-income developments can be linked to several phenomena. The first, and perhaps most important influence is the transition from a post-war Keynesian welfare system, to a new neoliberal influenced, market oriented policy agenda since the 1980s. As an emphasis on competitiveness and free markets has become more dominant in the policy realm, social housing policy, along with other social services has experienced a serious diminishment in status at the federal level. At the local level, changes in the management and structure of existing housing can also be contextualized against literature emphasizing the influence of competitiveness (Kipfer \& Keil 2002), creativity (Florida 2003) and "global city" formation (Sassen 2002). As cities compete to attract global capital and the 
accompanying global "gentrifier class", they are also contending with the effects of the retrenchment of the welfare state, increasing concentrations of poverty and the rise of "divided cities" (Van Kempen \& Marcuse 2002, Hulchanski 2007). The impact of a weakened social welfare infrastructure and the desire to appear "competitive" and "creative" thus adds complexity to the debate regarding the nature of public responsibility towards the supply of housing for low income earners and the appropriate spatial distribution of poverty.

Keeping these developments in mind, this paper seeks to explore the evolution of social housing policy in Toronto as well as provide insight into new "revitalization" initiatives. After identifying key trends in social housing, it compares these insights with the opinions expressed in interviews with key informants in Toronto's housing sector. The implications of this research reveal several important findings. First, in regard to the supply of social housing, it is clear that a safety net and an important coping strategy that once helped people weather the vagaries of the housing market is now destabilized and ill equipped to maintain itself, let alone to help address additional housing strains. Secondly, despite international examples and some research in the Toronto context that casts doubts on the proposed benefits of new "revitalization" schemes, key informants in the sector appear to have accepted the current agenda of the social housing sector and portray such developments as at least a "necessary evil" in the Toronto context. The entrenchment of such opinions, it is argued, marks a clear change from past priorities in social housing and also contributes to the overshadowing of the dismantling of the social housing sector at a time when it is most needed. 


\section{A Brief Review of Social Housing Policy and "Revitalization/Social Mix" Approaches}

Within the Toronto context, in order to understand the significance of current developments in the social housing sector, it is necessary to contextualize such developments within the wider realm of housing policy's evolution in Canada. As "revitalization" initiatives are promoted as a way of alleviating problems of underfunding and concentrations of poverty via the influx of higher income earners in social housing developments, the ideological undercurrents that motivate such proposals and their relationship to past policy must also be explored.

\section{The Origins of Canadian Social Housing Policy (1950s-1970s)}

As geographer Larry S. Bourne points out, "our definitions of housing problems and our approaches to housing policies are firmly embedded in particular national and cultural contexts" (As Cited in Purdy \& Kwak 2007, p.361). Within Canada, despite the country's reputation as a strong liberal welfare state, research has shown that in fact, Canada was "one of the last major western nations to introduce a social housing program" (Bacher Cited by Murdie 2004, p.180). Indeed, unlike the formidable state housing schemes adopted in many European countries after the First World War and the United States in the 1930s and 1940s, Canadian governments, particularly at the federal level, were initially slow to launch public housing projects, favouring a corporate-influenced policy agenda that spawned homeownership plans but little social housing (Purdy \& Kwak 2007, Harris 2000, Brushett 2007). In characterizing Canada's approach to social housing, writers such as Bacher (1993) described housing policy as "keeping to the marketplace." 
Despite a relatively late start, social housing policy in Canada did emerge as an accepted and necessary area of policymaking in the $1960 \mathrm{~s}$. Within Toronto, Regent Park was a predecessor to the more extensive housing provision schemes that would emerge in the 1960s and 1970s. In an effort to avoid the economic uncertainty witnessed in the United States and to allow slum clearance, Regent Park was initiated at the municipal level by the Housing Authority of Toronto in 1947 (Purdy 2003, p.522). Such a development, combined with amendments to the National Housing Act reflected a perceived moral need for intervention in the housing sector as well as public antipathy to urban produced slums. Within years, Canada would witness the creation of a federally funded and municipally run public housing program that allowed for a direct relationship between the provinces and the municipalities in Canada (Murdie 2004, p.181). Reflecting a more socially oriented ideological climate characteristic of post-war welfare states at the time, most of the approximately 200,000 government owned public housing units were built between 1964 and the 1970s (Murdie 2004, p182).

Concerns did emerge in the social housing sector in the 1960s. Although originally promoted as a method of urban renewal, the projects were expensive to maintain and within a decade were attracting negative publicity and stigmatization (Purdy 2003). A report by the 1968 Federal Task Force on Housing blamed the projects for "breeding disincentive" and a "what's the use" attitude to work and self improvement (Cited by Purdy 2003, p.46). Partly in response to such concerns, the design of social housing was changed in the 1970 s to allow for cooperative forms of housing and a greater mix of tenants. In the interests of achieving social mix and thereby avoiding the negative stigma attached to public housing, co-op housing was to be aimed at $25 \%$ of low income people, whose rent would be rent-geared-to-income (Wolfe 1998, p.124). 
Co-operatives were government own, but locally managed and "tend to be rather well functioning communities" (Hackworth 2009, p.261).

Despite the concerns expressed regarding the design and concentration of social housing developments, like other Western nations at the time, the interventionist policies of the government were clear in their recognition that the market alone should not dictate the supply of housing. When speaking of the role of governments in housing in 1963, Minister of Urban Affairs Ron Basford stated:

When we talk about people's basic needs- the requirements for survivalsociety and the government obviously have an obligation to ensure that these basic needs of shelter are met. I have already acknowledged this in stating that good housing at a reasonable cost is a social right of everyone in this country...[This] must be our objective, our obligation, our goal. ( Cited by Murdie 2004, p.181)

Years later, in a 1985 Consultation Paper on Housing, Canada's Federal Minister on social housing wrote that federal social housing programs "reflect a recognition that private markets, even well functioning ones, cannot deal with these problems" (Cited by Dreier \& Hulchanski 1993, p.56). Thus, although slow to start compared to other nations, even a conservative government recognized housing as a basic right and responsibility of the Canadian state. By 1988, there were almost five thousand public housing projects in Canada (Purdy \& Kwak 2007, p.364). Although not as generous a system as other countries, optimism was expressed in Canada's social housing sector for what appeared to be the creation of a "foundation for solving the housing problems of low and moderate-income groups on a permanent basis" (Dreier \& Hulchanski 1993, p.57). 


\section{Neoliberalism and the Dismantling of Canada's Social Housing Sector (1980/90s - present)}

In contrast to the optimism that was expressed for Canada's social housing sector in the 1950 s into the 1980 s, a turn to an ideological environment favouring neoliberalism significantly impacted social housing provision in Canada. Although Brenner \& Theodore (2002) are correct to suggest the difference between "ideal type" and "actually existing neoliberalism," the effects of an ideological mantra that stressed the liberation of individual freedoms, strong private property rights, free markets and free trade have meant considerable change in the social housing sector.

As with the initial acceptance of the principle of social housing, Canada's adoption of neoliberalism in the social housing sector also came relatively later than other countries. Indeed, even in the midst of other countries embrace of free market reforms (Thatcherite Britain and 'Reaganomics' in the United States), Canadians initially believed their social housing system to be relatively impermeable to such reforms. Writing in 1993, Dreier and Hulchanski noted a decline in the funding of social housing supply programs and a halt to the federal cooperative housing program, but stated "it is anticipated that a change in the federal government (to a Liberal party) will restore social housing allocations and the federal cooperative housing program"(p.46). Unfortunately for the social housing sector, federal funding for housing was not restored. Instead, the Canadian state gradually withdrew from social housing field altogether.

The 1990s have been characterized as the "onset of an assault on the social housing sector"(Wolfe 1998, p.121) wherein the newly elected Liberal government declared that housing for the poor was no longer the responsibility of the Canadian federal government (Hulchanski 2004). In Ontario, the impact of a federal withdrawal from social housing was further 
compounded by the Conservative government's removal of provincial funds. Motivated by a "faith in individual choice, the market, and an obsession with competition" (Kipfer \& Keil 2002), Premier Mike Harris's "Common Sense Revolution" further downloaded the responsibility of social housing from the provincial to the municipal level. Under the Social Housing Responsibility Act (SHRA) of 2000, the existing stock of social housing was downloaded to 47 service providers throughout the province. The intent of the SHRA was to "improve local delivery, innovation and forge a new relationship with the private market [or] in simple terms, to make housing providers behave more like businesses" (Hackworth 2006, p.516). Such changes were consistent with theories of "roll back and roll out" neoliberalism, or "creative destruction", wherein existing institutions of the welfare state were scaled back or destroyed and new models adopted in accordance with a more neoliberal orientation (Brenner \& Theodore 2002).

Although neoliberalism promises an increase in efficiency brought about by the freedom of individual choice, it is generally agreed that the changes in the structuring of social housing have not been beneficial. In a study to address the impact of the SHRA, Hackworth \& Moriah (2006) noted that "downloading, in the view of most respondents has not increased local expertise in the delivery of social housing but rather increased confusion and often inefficiency as local providers struggle to adapt to the new system" (p.518). Further, although a loosening of rent controls was predicted to induce the construction of affordable rental units in the private sector, not only have rents increased, but the "rent people can afford is not enough to elicit new private sector supply or a refurbishment of existing stock" (Hulchanski 2004, p.26). By placing responsibility for revenue generation primarily at the municipal tax level, serious shortfalls in 
funding have been evident. Glynn (2009) has characterized the role of neoliberalism in social housing as:

...almost everywhere, at the same time as social polarisation and soaring house prices have led to a growing need for cheap rented housing, social housing stocks have been restrained or often actively cut back.

Moreover, social housing stocks that remain are often starved of funds, depriving them of all but minimal repairs and maintenance. There is much talk about providing and improving social housing but this has rarely been backed by the necessary finance or action.(p.45)

While Canada's social housing policy was praised in the past as having "made outstanding progress relative to the United States in the area of affordable housing supply" (Dreier \& Hulchanski 1993, p.43), the impact of serious cuts to social housing calls these assertions into question. Although social housing enjoys more public support in Canada than in the United States, the Canadian (and Ontarian) sector is numerically marginalized by almost any other international comparison (Hackworth 2008, p.10). For example,

Canada has about $5 \%$ of its housing stock in the social rented sector and has no shelter allowance. The UK has $20 \%$ of its national housing stock in the social rented sector and has a universal shelter allowance (the Housing Benefit). The Netherlands has $40 \%$ of its housing stock in the social rented sector and has a shelter allowance (not quite as extensive as the UK Housing Benefit). (Hulchanski 1997, p.4).

These developments have also grown negative international attention. The United Nation's Committee on Economic, Social, and Cultural Rights has documented Canada's housing and homeless problems as being in a state of "national emergency" and urged the Canadian government to implement a "national strategy" (Cited by May 2007, p.2). Despite a change from a provincial Conservative to a Liberal government in 2002, neoliberalism appears firmly entrenched within the policy realm as it is argued that "little has or will be done to actually reverse the latter's policies on health care, social housing, and education" (Hackworth 2008, p.8). 
Activists within Ontario's social housing sector have found themselves in a "political quandary", faced with memories of a Tory government that was openly hostile to social housing, or a Liberal government that has "quietly acquiesced" to the model put in place by the Conservatives (Hackworth 2009, p.264). The space for contestation appears narrow.

\section{Spatial Dimensions of Poverty and Ethnicity in Social Housing}

In addition to what may be termed a crisis in affordable housing in the neoliberal era, concerns relating to the changing spatial and ethnic character of social housing cannot be overlooked. Although social housing has long generated controversy for the concentration of low income groups, recent concerns coupled with the scarcity of available social housing have led to new debates. Within Europe and especially Britain, research conducted has focussed upon issues of discrimination and unfair allocation of council housing to immigrants and visible minorities (Robinson 2002, Rutter \& Latorre 2009). Although such research has not been as prominent in Canada, concerns have been expressed regarding the increasing segregation of low income groups and visible minorities in specific cities (United Way 2004). While most newcomers to Canada find accommodation in the private rental market, social housing in Canada's largest cities is increasingly occupied by immigrant populations (Wayland 2007, p.25). As the demographic shift in Canada appears to be pointing towards immigrants comprising a larger sector of the population, this shift is expected to significantly impact the tenant profile of social housing (Moskalyk 2008). Thus, it has been suggested that "any debates about the future of social housing in immigrant-receiving cities should take into consideration the arrival and settlement needs of newcomer populations" (Wayland 2007, p.25). 
The reasons behind many immigrants choosing to live in social housing relates to their increasing difficulties in the Canadian housing market. While many immigrants benefit from successful housing careers, data also reveals that some are having increasing difficulty finding housing that is adequate, affordable and suitable (Murdie 2004, CMHC 2006). According to 2001 census data, $36 \%$ of recent immigrant households were living in unacceptable housing conditions ("core housing need"3), compared to $13.7 \%$ for non-immigrant households (Cited in Wayland 2007, p.4). Further, despite earlier literature that pointed to rapid upward mobility for immigrants in the housing market, new literature shows that such mobility may not be realized by the most recent groups of immigrants (Preston et al 2009, CMHC 2006, p.2). From a social inclusion perspective, these findings are unsettling due to housing's role in the settlement process. As Wayland(2007)writes, “...secure housing and inclusive neighbourhoods establish the circumstances for access to a range of other formal and informal supports and networks that facilitate the resettlement and integration process" (p. 23). Given the declining economic mobility of recent immigrant groups relative to previous waves of immigrants, this finding may not be surprising.

As residential patterns change in the context of globalization and increasing gentrification, concentrations of poverty such as those found in large social housing developments have often been interpreted as negative phenomena. They have also led to concerns over the extent to which integration and social inclusion may be inhibited in large scale social housing developments. At the same time however, it should be noted that such interpretations may overlook their importance in providing access to important services, enclave

\footnotetext{
${ }^{3}$ According to Canada Mortgage and Housing Corporation, "Core housing need refers to households which are unable to afford shelter that meets adequacy, suitability, and affordability norms. Affordability, one of the elements used to determine core housing need, is recognized as a maximum of 30 per cent of the household income spent on shelter". (CMHC online)
} 
effects and institutional completeness ${ }^{4}$. It can also be argued that the stigmatization of low income areas tends to mask the effects of a weakened social welfare sector and rising inequality in the context of neoliberal influenced reforms. In the context of "global cities", as Robinson (2002) points out, a "conflation of social exclusion and social housing reflects the increasing emphasis in public policy on neighbourhood deprivation, related to the view that concentrations of deprivation represent a burden and a damage to competitiveness" (p.109).

\section{"Social Mix" and Social Housing in a Neoliberal Era}

In the context of increasing fiscal constraints, deteriorating social housing infrastructure and the increasing stigmatization of low income areas, new "social mix" initiatives have taken centre stage in the discourse on social housing. Although relatively new to the Canadian context, such developments have gained increasing ground in Western Europe and the United States. Inherent in these initiatives is the idea that remodelling the physical structure and social composition and physical design of public housing communities could solve several issues at once. Thus, its adherents argue that social mix strategies may address the social and economic problems that face tenants, save money for the housing agency, and contribute to city wide goals of increasing tax revenues, economic development, and tourism (August \& Walks forthcoming). As a result of traditional concerns about concentrated poverty and the current political economic climate, much of the discussion surrounding social mix "can reflect a variety of objectivesranging from fighting social exclusion to stabilizing a municipal tax base- and can be embraced by those espousing ideologies ranging from egalitarian to neo-liberal" (Rose 2004, p.280). The initiatives also fit well with the image of a liveable or "creative city" wherein a key aspect of the city's ability to compete in a knowledge based economy (Florida 2003) relates to cities'

\footnotetext{
4 Previous work has argued that the clustering of groups and the presence of ethnic "enclaves" in Toronto has been beneficial to their sense of community and integration in Toronto (Murdie 1998, Siemiatycki et al. 2003)
} 
marketing themselves as being built on a foundation of 'inclusive' neighbourhoods capable of harmoniously supporting a blend of incomes, cultures, age groups and 'lifestyles' (Rose 2004, p.281).

However, it should be noted that "social mix" or mixed income development is primarily a market based strategy to address urban poverty. As such, it uses public-sector investment and incentives to promote a free market orientation on the part of individuals and developers as a way of inducing neighbourhood revitalization. As Thibert (2007) points out, "social mixing is usually proposed as a solution to 'segregation' and 'exclusion' and as a means of achieving 'diversity"' (p.6). Much of the existing literature on social mix initiatives tends to put forth similar rationales. In a review of studies, Joseph et al. (2007) propose four main theoretical rationales for "mixed income development" (social mix development strategies). A social networks argument proposes that by moving higher income households into close proximity with lower income groups, social networks will develop and lead to information exchanges and enhanced opportunities for the marginalized. A "social control" rationale posits that "the presence of higher income residents will lead to higher levels of accountability to norms and rules.... and thus increased order and safety for all residents" (p.373). Next, a behavioural argument suggests the presence of higher income people will lead to role modelling and the promotion of self-efficacy on the part of lower income residents in new "socially mixed" neighbourhoods (Joseph et al. 2007). Finally, the "political economy of place" argument suggests "the influence of higher-income residents will generate new market demand and political pressure to which external political and economic actors are more likely to respond" (p. 373). Essential to all of these approaches is the idea that concentrations of middle class actors will bring benefits to the community that will essentially trickle down to low income residents. 
"Trickle down" neoliberal economic theory popularized by Ronald Reagan in the United States is thus transferred to ideas regarding socialization.

Reflecting social mix strategies' increasing popularity, there exists a significant amount of literature. Generally, however, evidence to date from international comparisons does not support the purported positive outcomes outlined above. While in some cases the latter two propositions (behavioural modelling and "politically economy of place") have occurred, as Fraser \& Nelson (2006) conclude, "mixed income initiatives appear to be more effective in improving the physical quality and atmosphere of the neighbourhood than in creating social mobility opportunities for low-income households" (p.2134). Further, and significant in the context of concerns for social inclusion, Joseph et al. (2007) suggest that "it is also possible that low-income families may experience significant personal and familial challenges in the new environment, including social isolation, stigma, a sense of relative deprivation, increased scrutiny, and competition with more affluent residents for scarce local resources" (p. 209). In the context of literature that stresses the economic competitiveness of cities, as August (2008) writes, "(e)ngaged with improving the image of a liveable city to meet economic goals, social mix policies may perversely promote social exclusion, by necessitating the removal of 'undesirables' in order to achieve a desired social composition" (p.91).

Concern has also been expressed regarding the extent to which "social mix" may simply exist as a land grab or a form of state sponsored gentrification. In the context of the United Kingdom, it has been noted that the regeneration of housing schemes in the city centres have been particularly susceptible to such developments that are openly conceived as ways to attract richer new residents rather than improve conditions for existing residents (Glynn 2009, p.74). Initial results appear to support Fraser \& Nelson's (2008) argument that "the majority of benefits 
have been realized by private-sector developers, local government, and other stakeholders who are in the position to benefit from place-based revitalization" (p. 2129). The desire to move middle and upper classes into the city without confronting the reality of social housing and simultaneously moving out undesirables does not point towards a positive outcome. Instead of benefitting all residents, they appear to parallel Fraser \& Nelson's (2008) argument that:

Urban redevelopment policies including ones said to have the goal of ameliorating poverty and providing opportunities for environmental improvement for low income populations, can be alternatively examined in terms of their potential to spur urban revitalization for incoming middle class populations. (p. 2136)

Such schemes fit comfortably with urban neoliberal projects that seek to attract the "right type" of resident, i.e. "the young, cool, educated, high-value added worker of the knowledge economy" (Brenner \& Theodore 2002).

In addition to the lack of evidence supporting the rationale for social mix, it should also be noted the role of redevelopment schemes in overshadowing the diminished role of the state in social housing provision. Unsettling to observers has been the apparent overlooking of sustained neglect of social housing developments that an imposition of neoliberal measures and social mix does little to ameliorate. Instead, a social mix rationale appears to interpret the stigmatization of low income areas as natural tendencies. As social housing developments fall into disrepair, the "go to" solution in many contexts appears the introduction of a more affluent population in a market oriented scheme to gentrify the area. The role of government in such contexts appears to be the facilitation of the privatization of once public goods, what Harvey (2005) has labelled "accumulation by dispossession", whereby public goods are reallocated towards private profit through a legitimized theft of the commons. In the Canadian context, the re- development or revitalization of social housing developments represent a distinct shift from past policy stances in 
social housing. As Dreier \& Hulchanksi (1993) once acclaimed, "A key feature of all of Canada's social housing programs is that the land and housing units are permanently removed from the real estate market" (p. 53).

\section{The Case of Toronto}

Toronto serves as an important case study for the effects of changes in housing policy and the concerns expressed in literature on social housing. Not only is Toronto home to the country's first social housing development, but it is also the site of the country's largest social housing provider, Toronto Community Housing (TCH). As the city continues to attempt to handle significant cutbacks in funding and the downloading of many social services to municipalities since the 1990 s, it is also influenced by a new, highly neoliberal and competitive ethos that seeks to shape the city as a prime investment platform. In a ranking of "global cities" by Foreign Policy, Toronto was ranked tenth in 2008. As Invest Toronto writes,

An attractive place to live, prosper and grow a business - Toronto. Invest Toronto is rooted in one of the fastest growing metropolises in the world. Our mission is to promote Toronto as a prime business destination for new investment. By telling the Toronto business story, Invest Toronto will help businesses realize the benefits of this global City. (online)

The increasing emphasis on competitiveness and creativity must be contextualized with rising welfare rates and increasing income stratification in the city ${ }^{5}$.

Within the social housing sector, the withdrawal of federal and provincial responsibility has seriously affected the ability of social housing providers in the city to respond to existing or new needs among those experiencing housing affordability problems. As a result of the withdrawal of funding, no new social housing has been built in the city of Toronto since the early

\footnotetext{
${ }^{5}$ Fanelli \& Paulson (2010) cite that between 2008 and 2010 welfare caseloads in Toronto have increased by nearly $25 \%$.
} 
1990s. In the year 2008, the City of Toronto reported a $\$ 300$ million dollar shortfall in the amount of funds available to bring Toronto's existing social housing stock to a state of good repair (City of Toronto 2009). As the city suffers from what has been labelled a "despairingly tight housing market" (Purdy 2002, p.45), the waiting list for social housing units in Toronto was recorded in 2009 at 138,075 individuals (Housing Connections 2009, p.1) ${ }^{6}$.

In addition to a scarcity of affordable housing in the city ${ }^{7}$, spatial concentrations of poverty have also drawn increasing concern. Several reports have documented an increasing segregation of low income groups in the city (United Way 2004, Hulchanski 2007). According to David Hulchanski (2007), Toronto now exists as a "divided city" in which poverty has surged northwards geographically and the middle class appears to be disappearing. For the many newcomers who come to Toronto each year, the lack of affordable housing within the city of Toronto, has meant settling outside of the city in areas more remote from newcomer services as well as essential infrastructure (Preston et al. 2009).

Within the social housing sector, the ethnic composition of social housing has changed greatly since the 1950 s and been affected by changes in Canadian immigration policy, the worsening economic outcomes of immigrants and the racialization of poverty ${ }^{8}$. Ley and Tutchener (2001) suggest that since much of the Toronto's population is composed of immigrants and many were refugees with little resources upon arrival, Toronto's immigrants have depended on the social housing sector more than other immigrant receiving cities such as

\footnotetext{
${ }^{6}$ In 2009, approximately 5,000 people on the housing connections waiting list were housed (Housing Connections 2010).

${ }^{7}$ Vacancy rates have remained low in Toronto since the 1990 s and despite a peak of $4 \%$ in 2004 , were recorded at $2 \%$ in 2008 by the CMHC (online).

8 "About one-third of non-Europeans living in Toronto live below the poverty line and-although they make up only $36.9 \%$ of all families in Toronto- account for 58.9 per cent of all poor families in the city" (Ornstein 2006 cited by Boudreau et al 2009, p.86).
} 
Vancouver. Within Toronto, social housing developments such as Regent Park have been termed "racialized spaces" (Sahak 2008) in which a disproportionate amount of their population is of visible minority or immigrant background. In Regent Park, 80 per cent of the residents have been documented as people of colour, most of whom are immigrants (Kipfer \& Petrunia 2009, p.119).

\section{Revitalization/Social Mix Initiatives at Toronto Community Housing (TCH)}

Much like other cities facing serious financial shortfalls in the social housing sector, within Toronto attention has turned towards the "revitalization" of existing social housing developments. As with the "social mix" initiatives mentioned earlier, the intent of such projects is to leverage public assets for the reconstruction of housing developments that will become home to market rate condominiums as well as subsidized units. In the process, existing tenants in selected sites are relocated to alternate homes as their old buildings are demolished and replaced with new "socially mixed communities". As of 2010, thirteen of TCH's existing sites have been targeted for "revitalization". Most prominent among the sites is the Regent Park redevelopment that is currently underway and the Lawrence Heights proposal that is set to begin next year. Both developments were originally constructed in the 1950 s/60s and now occupy prime real estate areas of the city.

As might be expected given developments elsewhere, $\mathrm{TCH}$ argues that by bringing middle-class residents into high-poverty areas, tenants will benefit from enhanced social integration, better employment and economic outcomes, and upward social mobility. TCH has marketed the projects in positive terms for the community and as a much needed revenue generation strategy. According to TCHC (online), "Revitalizing our communities creates mixed income neighbourhoods that feature new affordable and new market housing units, integrating 
tenants with the broader community". The revitalization strategy includes five "key components":

1) Following a financially viable plan that leverages the value of land, increased density in units, additional financial opportunities, and new partnerships to offset the cost of new construction

2) Engaging the community throughout the revitalization process

3) Creating sustainable communities by pursuing high-performance green buildings and innovation to reduce energy and water costs

4) Integrating excellence in planning, urban design and architecture

5) Providing economic opportunities to tenants throughout the process (TCH 2010).

Despite the optimism that TCH expresses for new "revitalization" strategies, concerns have been expressed among activists and academics that mirror larger debates in the social mix literature. In Toronto, the concern over the rights to space and property for certain groups of people has been juxtaposed with an agenda to recolonize inner city land (August 2007, Kipfer \& Petrunia 2009). In the case of the Lawrence Heights revitalization, an area where 1000 lowincome units are presently located, 5000 new middle income units are expected to be incorporated into the "revitalized" development, a ratio of approximately 5:1 (Moloney 2010). The potential for power imbalances in revitalized communities has already been observed in Toronto by August \& Walks (forthcoming). According to their study, redevelopment creates significant power imbalances between the subsidized tenant minority and the new majority residents paying market rates for their housing. The authors suggest that "social housing redevelopment as carried out in Toronto portends the dilution of tenant organizational power, and the marginalization of tenant political voice" (August \& Walks forthcoming). Rather than pointing to enhanced social networks and inclusion, it is suggested that "redevelopment has the potential to diminish the political influence of tenants in local decision-making, in local electoral politics, and in consultative processes with TCHC" (August \& Walks forthcoming). 
In addition to concerns over the rights to space and political marginalization, a research study by Schippling (2007) that sought to explore the experiences of relocated tenants does not point to positive outcomes. Schippling noted that "after one year, the residents participating in this study are not making connections in their new neighbourhoods at all comparable to the ones they had in their former neighbourhoods" (p. 145). He also pointed to the disruption of social networks, suggesting that "the previous relationship of many phase 1 residents among their friends and neighbours had formed an important social support system that has not yet been achieved in new neighbourhoods" (p. 146). These findings are especially troubling in that prior literature on Regent Park had pointed to strong social networks and community organizations among residents (Purdy 2003).

From the literature considered here, it is clear that current "revitalization" projects in TCH represent a significant shift from the original orientation of the Canadian state to the provision of subsidized housing. Despite a mounting body of literature that criticizes new "social mix" schemes, the popularity of new "revitalization" initiatives among the city's social housing planners does not appear to be waning. Such developments and the promotion of "revitalization" as a positive development in the Toronto context appear increasingly at odds with existing literature on "social mix" and the scarcity of social housing units within the city. This paper will now consider the views of actors with work experience within and related to social housing in Toronto.

\section{Research Design and Methods}

The purpose of the interviews conducted here was to analyze to what extent the opinions of key informants involved in Toronto's affordable housing sector reflected or could provide 
new insights into the arguments expressed in academic literature. To answer this question, a qualitative research approach was chosen. The reasons behind the choice of a qualitative approach for the study included the relative paucity of research that had been conducted on housing workers' views concerning revitalization, the exploratory nature of the research itself, as well as a desire to give voice to the participants involved while allowing for creativity in the research process (Creswell 2009). The research was not aimed at achieving a representative sampling, but rather was a purposeful sampling that intentionally sampled a group of people that could best inform this researcher about the research problem under examination (Creswell 2007).

This study was originally planned to consist of ten face-to-face, semi-structured interviews with key informants. The questions (Appendix I) were part of a larger study conducted by Professor Sutama Ghosh of Ryerson University. An interview format was chosen because interviews allowed for a more in-depth engagement with the topic than a survey or focus group would have permitted (Neuman, 2000). Also, one-on-one interviews allowed for an increased measure of confidentiality and flexibility in scheduling a convenient location and meeting time between participant and researcher. The choice of semi-structured interviews was made because the method is appropriate for qualitative and exploratory research of this kind. The use of semi-structured interviews allowed the respondents to answer open-ended questions with a discussion of the issues that they felt were most important, thereby minimizing the biases and preconceptions of the researcher (Schippling 2007).

Face to face interviews were chosen over email communication or telephone interviews because of the ability to probe more directly, witness informal communication and establish a rapport with participants. All interviews were conducted in the summer of 2010 . The final 
number of interviews conducted was six. This was due in part to either scheduling problems or a reluctance on the part of some individuals to participate in the research.

\section{Participant Recruitment}

As suggested, a purposeful sampling method was used to recruit individuals. The participant criteria for the study was that individuals self-identify as persons with recent, direct knowledge or sustained engagement with issues of affordable housing in Toronto. An attempt was made to capture a variety of persons who worked as housing workers, housing managers and individuals involved in affordable housing administration or government in different geographic areas of the City of Toronto.

Several methods were used to recruit participants for the study. The first method was through referrals from professors working in the housing field. Several meetings and presentations relating to affordable housing in Toronto were also attended wherein I established contacts and requested referrals to those interested in my research. From this point, I was able to email and phone suggested participants to tell them more about my research and request their participation. Each participant received a detailed email explaining the research and requesting their involvement as either a key informant in the study or as a referral to others working in the housing sector. Following each interview, participants were asked for the contact information of any others whom they believed could act as key informants in the study. This snowball sampling method was effective in leading to more people and information. For the most part, individuals were quite willing to participate in the research if their schedules allowed. Recruitment of individuals from the government sector and different social housing staff proved more difficult. 


\section{Participant Information}

In total, six persons participated in the interviews. Four of these individuals were classified as working in the not-for-profit, non-governmental sector. Two of these individuals were classified as working within government or social housing administration. Of those working in the not-for-profit, non-governmental sector, two of the individuals were housing managers and two were housing workers.

Key informants ranged in the number of years spent working in the housing sector. The least amount of time in the sector was two years. The longest was over 20 years. Each of the informants had received some post-secondary education, some at an advanced, graduate level.

Table 1: Participant Information

\begin{tabular}{|l|l|l|l|}
\hline Pseudonym & Education & Organizational Background & Years In \\
& & & Position/Sector \\
\hline John & Postsecondary & Not-for-profit NGO & Over 30 \\
\hline Bill & BA & Government/Administration & Over 25 \\
\hline Marie & MA & Government/Administration & Over 4 \\
\hline Susan & MSW & Not-for-profit NGO & 1 year \\
\hline Jessica & BA & Not-for-profit NGO & 2 years \\
\hline Charles & MSc & Not-for-profit NGO & 10 years \\
\hline
\end{tabular}




\section{Data Collection}

For the interviews, all participants were given the choice of interview location as well as their preferred recording method (audio recording or notetaking). I encouraged participants to choose a place of their convenience. In all, each respondent requested that I come to their workplace to conduct the interview. For each key informant, voluntary consent was obtained for their participation in the study.

On average, interviews lasted approximately one half hour, with the shortest time being approximately twenty five minutes and the longest approximately two hours. I attended most interviews with my supervisor, Professor Sutama Ghosh, who assisted with data collection. Other research assistants in the project, Naomi Arsenault and Sreya Banerjee also helped with data collection. It was evident from early on in the research that most participants did not wish to have the interviews recorded, therefore, most of the data collection occurred through note taking. Upon completion of the interview, notes were transcribed into the computer by the notetaker and sent to the interviewer to cross check for accuracy.

Several research questionnaires were used in the data collection (See Appendix I). The scope of the questionnaires was quite broad and allowed participants the freedom to talk about the issues that were most relevant to their position and experience. Questions focused upon individuals' opinions regarding: 1) the current housing situation in Toronto; 2) immigrant housing needs; 3) possible ways of solving the housing crisis in Toronto, especially, the role that could be played by the social housing sector in this regard, 4) large scale revitalization efforts of social housing complexes recently undertaken by $\mathrm{TCH}$; and 5) the potential effects of large scale revitalization of social housing projects. Questions were designed to be open-ended and not 
conducive to "yes" or "no" responses. Depending on the respondent, some questions were changed or omitted from the interview. Questions relating to challenges and potential benefits of the revitalization project allowed the respondent to reflect on the future of such social housing initiatives in the city.

\section{Data Analysis}

Ongoing data analysis took place throughout the study. To protect the anonymity of individuals, upon transcribing the interviews, the names of participants were disassociated from the data (Ex. Participant A became John Smith). From this point, ideas were sketched out, summaries compiled and codes identified. The coding of interview data was guided by the research question. During data analysis the data was organized categorically, reviewed repeatedly and continually coded. Data was coded using as many categories as possible. From the data collected, a list of codes were compiled which were then narrowed into large metathemes. Coding was also influenced by pre-existing codes derived from specific aspects of the literature collected. The same process was utilized to analyze content in web materials, documents and reports collected. To help ensure validity, the data analysis process was examined by a peer examiner in the graduate department.

\section{Limitations}

The limitations of this study include the limited number of participants. Taking this factor into account, this research project does not seek to be representative of the views of all individuals working in the housing sector. This study does however, provide a glimpse into a perspective that has not been rigorously explored and thus, it is hoped will add to the existing literature regarding social housing in Toronto. 


\section{Findings/Analysis of Interviews}

The following is a summary and analysis of the opinions expressed by key informants in this study.

\section{Respondents' Impressions of Housing Situation in Toronto}

In general, all the respondents expressed their concerns about the current rental housing situation of Toronto. Most were quite sceptical of change and expressed growing frustration with the present housing system as well as intensifying challenges in the past few years. Much of this related to the worsening of the economy in recent years and the growing demands put upon housing workers in dealing with a growing demographic group (the elderly), as well as an increase in demand for services for those with mental problems or addictions. As one participant informed us, he kept hoping for change, but nothing happens, "reality sucks" (John: 2010). In contrast to individuals working "on the ground", one government employee however, expressed more optimism regarding the housing situation. Bill (2010) responded that "overall, the majority of people in Toronto are well housed" and referred to Toronto as a historic leader in housing policy and the city's potential to influence higher levels of government.

In addition to more general concerns on affordable housing, in the process of the interview many respondents raised the issue that there was a mismatch between the spatial location of affordable housing and services for low income groups. As John (2010) revealed:

Everyone wants to live in the old city of Toronto. The makeup of the city shows the centralization of services. Amalgamation is still a huge problem in regard to services. In general, people plop here and then move to the 905 . Homeless people often remain in the downtown core. Everyone wants to live in the downtown core and pay $\$ 149$ per month and walk to services. 
The concept of "spatial mismatch" is not new to research on low income areas. Although the term was initially applied to describe the geographic barriers for inner city residents that arise from changing social and economic relations and the impact of such barriers on employment (Kain 1992), it has also been used in the context of access to welfare services and inadequate transportation networks (Blumenberg \& Manville 2004). Concerning the integration of newcomers, it has been estimated that forty percent of newcomers live in the northern areas of the Toronto region, but only $20 \%$ of services are located in that area (Truelove 2000 ).

The issue of "neighbourhood effects" was also prominent in conversations with housing workers. Neighbourhood effects refer to community influences on individual social or economic outcomes and the idea that the demographic context of neighbourhood can instill dysfunctional norms and values into individuals from which residents may have difficulty escaping (Bauder 2002). Although links have been established statistically, debates remain regarding the extent to which "neighbourhood effects" may be used as a political tool to reinforce negative stereotypes and blame inner city communities for their own marginalization (Bauder 2002). In the case of this project, housing workers were critical of the behaviours of those in low income areas, noting the potential for drug activity and crime. In her interview Jessica (2010) (a housing worker) noted the conflict between "neighbourhood effects" and the "spatial mismatch" of amenities.

...a lot of the areas that have amenities close, they're the highest poverty rate in the smallest geographical area and you're putting people into... rough areas and that's something that, yeah, we know we're putting you, but realistically, with the money that you have, you can't afford anything else, so if we can get them into private housing outside of an area, they're choosing to be in an area where they're secluded from grocery stores, transit not so much, transit is pretty good, but they don't have money for transit (Jessica: 2010). 
Later in the interview, Jessica (2010) would also express her dislike of the "toxic environments" that TCH housing represents in many parts of the city.

\section{Immigrant Housing Needs}

Generally, immigrants' housing needs and their experiences seeking affordable housing did not emerge as central elements in our interviews. For those working in government/housing administration, both respondents noted that the housing problems of immigrants, while not prominent in their respective agendas, were a component of a larger agenda to improve the affordable housing situation in the city. This viewpoint was consistent with research by Papillon (2002, p.20) that has stressed that in light of fiscal constraints, most housing services for immigrants have been targeted towards emergency measures such as temporary shelters.

Among housing workers, the opinions of immigrants' housing needs emerged from their own experiences with clients. One housing follow up worker (Jessica 2010) expressed concerns regarding specific needs of immigrants including language supports and a need to help "smooth their transition into Canadian lifestyle." Interestingly, while Jessica pointed to the need for supports for immigrants, it was revealed to us by another housing worker (John) that immigrants were perceived as an easier population to serve. As he responded, "refugees are a bit of a slam dunk. In general they present well, [are] well dressed, educated, well spoken, they advocate for themselves"(John 2010). At the same time however, John did express some frustration with the little he could do for non-status persons in the city. Although Jessica did not share the exact same sentiment as John, it should be noted that while working in an area with a high concentration of low income immigrants, it was revealed that few of her clientele in the housing follow up program were immigrants. 


\section{Solutions and the Role of Social Housing in Addressing Housing Situation in Toronto}

In the interviews, participants were asked to express some possible solutions with respect to surmounting housing problems in Toronto. Responses offered included measures to address the issue of rooming houses ${ }^{9}$ in Toronto, the state of $\mathrm{TCH}$ housing stock, and prospects for new affordable housing in the city. Interesting to note, much of the conversations with those involved in the non-profit, non-governmental sector were dominated initially by accounts of the private rental market and related supply problems. Among these individuals, the importance of funding was acknowledged, but the role of the social housing providers or rent-geared-to-income initiatives were not strongly emphasised. Instead, much of the focus of non-profit, nongovernmental housing workers and managers focused upon raising awareness about rooming houses (a private market response) and hidden homelessness.

When the role of social housing providers in solving the housing crisis in Toronto was further probed, one housing manager responded that:

obviously their role in an ideal world would be to essentially create more affordable units, but given the fact that it is not possible, there may be advantages for them to look into alternate ways of providing affordable housing such as a mixed model use...(Charles 2010).

Such a response represented a clear shift away from earlier conceptions of social housing and an apparent resignation if not outright encouragement of a more neoliberal, market oriented form of service provision. It was also reminiscent of the "there is no alternative" mantra of

\footnotetext{
${ }^{9}$ According to the City of Toronto, a rooming house is a building that contains dwelling rooms and may also contain one or more dwelling units, where: The dwelling rooms, in total, are used or designated or intended for use as living accommodation by more than three persons; and the living accommodation is provided in exchange for remuneration. Rooming houses are only legal in the former City of Toronto. In the former City of Etobicoke, there are licensed lodging houses which are licensed by Toronto Public Health. In the former Cities of North York and Scarborough, rooming houses are illegal. (City of Toronto Online)
} 
neoliberalism. For Charles, the previous era of construction of social housing was now off the agenda and a new, "social mix" model seemed more realistic.

Perhaps the most revealing aspect of these accounts was the idea that the lack of greater state intervention in the rental housing market appeared to have been normalized among those working in the housing sector. Although those working in government/housing administration clearly identified the need for expanded funding for existing housing initiatives as a key priority in solving the affordable housing situation, those working "on the ground" did not share such sentiments. Indeed, a degree of pessimism was again evident in the responses. For one housing worker who had been engaged in the sector for a prolonged period of time, a sense of acceptance was evident in regard to Toronto's housing situation. As he said, "Toronto is what it is", "Ontario works pays what it does"(John 2010). The idea that increasing need necessitated a governmental response to the provision of housing was dismissed early in the interview as he responded,

The wait list is now 80,000 . We used to have to ask if people were on the wait list, put them on it. There was a requirement from the city to do this and it created a huge spike. It was thought that this would induce government action. But they won't give us money. We need a new strategy. The government will never build social housing again, but perhaps subsidies (John 2010).

Other housing workers expressed similar sentiments but also stressed the decaying state of existing TCH buildings as a serious problem. As Jessica (2010) stated, "pretty much all TCHC buildings are infested with bedbugs...some people don't want to live in TCH buildings because they know what they're like". Another worker also expressed frustration with the social housing system, remarking that even after years of waiting, acquiring a subsidized unit could not detract from the fact that "it's still a TCHC building"(John 2010). He then offered an account of 
one of his clients' experiences moving to a building with drug and gang activity, his fear of living in the area and latter loss of his subsidy (subsidies are not transferrable).

The likelihood of actually acquiring subsidized housing was also expressed repeatedly in interviews with housing managers and workers. As one respondent stated, "the subsidized units and the allocations with that is like, literally, a draw" (Jessica 2010). While there is interest to live in social housing, Charles (2010) commented upon the misconception among clients that there are units available.

\begin{abstract}
you see that people know about affordable housing, so just, so there is a lot of interest in terms of getting applications in, so that they can eventually get affordable housing, I think the priorities are, I mean essentially you have to be a victim of domestic violence or you have to, pretty much, you have to have a terminal illness right....it is difficult to get...people out of that situation, to explain to the community at large, because we become the buffer between TCHC whose policies over we have very little control and the community which seems to think that there is actually a lot of affordable housing available.
\end{abstract}

The interviews with housing workers/managers displayed a clear degree of pessimism and a change from past periods of Toronto's social housing wherein social housing represented a significant social safety net in the city.

\title{
A Changing Role
}

Although individuals working in government/housing administration were more optimistic about the "significant social safety net and need for ongoing federal/provincial funding investments"(Bill 2010) in the social housing sector, a theme that emerged in the interviews was that of an internal focus in the management of existing social housing in the city. John expressed scepticism in the management style of TCH. According to John (2010), 
TCHC is a large corporation and it is overwhelmed by the waitlist. Two years ago half the staff was pinkslipped. If there's a problem with a TCHC unit, often the response is to evict....The staff answer the phone and later cry, they don't want to work there, slamming down the phone. They are completely overwhelmed by the workload. They are a corporation, not social workers. As soon as someone doesn't pay the rent, or if the rent is late, they file for N5 and are on top of evictions.

His viewpoint was consistent with previous studies documenting an entrepreneurial rather than social ethic in social housing administration (Hackworth \& Moriah 2006).

The changing role of TCH was evident in an analysis of documents as well as in interviews with participants. As TCH (2010b) writes in its management plan, "we operate as a business, meeting the financial expectations of a landlord...we also carry a social and community mandate to build strong neighbourhoods and sustainable communities." Within government/housing administration interviews, both respondents focused more on the changing nature and existing maintenance needs of social housing in regard to housing environments. As Marie (2010) stated,

Social housing was set up to be a temporary solution but that is no longer the case. Social housing has become multi-generational, families and children are staying in the same communities because of networks and the high costs of housing... TCH wasn't originally set up to deal with community issues, but to house a high number of vulnerable people...it's a challenge getting tenants to engage in the community. There's a challenge communicating, constantly changing demographics.

This stress on community engagement may be interpreted as a positive phenomenon but should also be contextualized against August \& Walks (forthcoming) article that highlighted several problems in TCH's community engagement process ${ }^{10}$.

\footnotetext{
${ }^{10}$ August \& Walks (forthcoming) used a measurement named the Ladder of Citizen Participation by Arnstein to gauge citizens' experiences in the community consultations. The concluded that "While the language contained in the TCHC documentation, written into redevelopment studies, and espoused by the planners working for TCHC implies democratic decision-making and full citizen control...on the ground the forms of participation that transpired never soared above the lowest possible rung, what Armstein terms manipulation".
} 


\section{Revitalization Efforts at TCH}

Opinions regarding new "revitalization" initiatives were interesting with regard to gauging individuals accounts vis a vis existing published literature as well as institutional vs. "on the ground" accounts of the perceived benefits and challenges of such projects in Toronto. Perhaps surprisingly, all of the individuals interviewed in the study regarded "revitalization" in fairly positive terms for TCH. As Bill (2010) stated:

I think that these are terrific because these communities were built in a specific time period. The new objective is to weave them back into the fabric of the city. It also brings homeownership opportunities and breaks the cycle of poverty. They're community led, it's the community making the decisions. TCH has been successful in engaging residents and supporting and defining what development should be so that it's not a process that's happening without them, they are shaping it.

Contrary to academic literature that criticizes "social mix", initial opinions in these interviews indicated that "revitalization" was seen as a favourable option in addressing problems within current social housing. "Social mix" was highlighted as an important aspect of the new projects in that previous planning of social housing was believed to have created negative neighbourhood effects for tenants and a sense of segregation from the outside community.

When probed specifically as to what effect "revitalization" may have on immigrants living in TCH buildings, respondents once again saw "revitalization" as a positive development. In addition to providing safer communities for immigrants to live in, it was also noted the possibility of mentorship opportunities, English language opportunities and social inclusion initiatives wherein "they are being asked what they want to see, perhaps this hadn't been the same in their home country" (Bill 2010). Overall, the responses were quite consistent with the image put forth by TCH of "great neighbourhoods", improved amenities, job opportunities, and community engagement" (TCH online). As one housing manager replied, 
In my opinion, if you have mixed income housing there is not so much of ghettoization. I do believe that in mixed income housing you can have friends who are on welfare as well as wealthy people. Living with high income people, people can still feel marginalised but housing marginalised people with middle or high income people can still be helpful. (Susan 2010)

Perhaps surprisingly, Marie, an individual in government/housing administration was the only respondent to touch upon issues of marginalization or outside examples of "social mix". Despite her awareness of the criticism in the international context, she believed Toronto an exception to outside examples of "social mix" because of TCH's emphasis on long term sustainability and quality of life.

\section{Potential Effects of Revitalization on Torontonians in Housing Need}

When asked more specifically about possible challenges for "revitalization", many respondents initial reply was that it was more of a wait and see approach. Subsequent responses then focused upon financial concerns, the availability of services, and the effects on existing social networks. The most vocal in forecasting potential challenges was a housing worker concerned about the gentrification of the area. John (2010) noted his more than thirty years in the sector and predicted,

that particular social economic class will find this challenging and exercise their legal apparatus. There will be a geographical cure. Things will gentrify to the point where services will move... There will be significant problems for this population [the middle class] and they are less tolerant. They [the poor] can exist but not in my neighbourhood. The integration that had existed naturally will change.

Jessica (2010) also expressed concern about the transition and the availability of services for low income earners. She replied,

the only thing that I see with that is that is that those areas of concentration of poverty also have a lot of supports set up over decades 
to assist those individuals so it could be taking a lot of those supports away from people. But, this population is very resourceful and they're very resilient and they'll be able to get through it" (Jessica 2010).

Both Bill and Jessica expressed financial concerns for new "revitalization" initiatives. Bill expressed concern that such projects could only materialize in areas where a condominium market existed, and lamented the idea that such a funding model would not allow for the revitalization of other areas of subsidized housing. Jessica admitted to "mixed feelings" and scepticism as to whether middle income earners would wish to live in an area such as Regent Park that was so heavily stigmatized.

Perhaps surprising, the most vocal response regarding concerns surrounding 'social mix' came from within the government/housing administration. Marie (2010) stated that:

In Regent Park we see a gap in understanding of different ethno-cultural lifestyles. Social housing was not set up for multigenerational, taking people out that were attached to social networks, the housing may not be great but the community was... In terms of revitalization from a financial perspective it makes sense, but not in terms of landscape.

Interestingly, the same individual who earlier lamented the behaviour of TCH as a corporation, did not immediately volunteer any concerns regarding new "revitalization" projects as more consistent with an entrepreneurial or free market approach. In fact, no respondents specifically had problems with the privatization of a once public good. In the case of John (2010), who earlier in the interview criticized the corporate structure of $\mathrm{TCH}$, the "revitalization" initiatives were a "necessary evil, probably long overdue". 


\section{Discussion}

In comparing the opinions expressed in the above interviews to larger themes in outside literature, several parallels as well as inconsistencies arose. Although the interviews revealed a range of topics and concerns, perhaps most telling in relation to this study were the opinions given regarding the role of social housing providers and individuals' opinions of revitalization. From the interviews conducted here, it was clear that for most respondents, the role of government in providing a supply of subsidized social housing was a thing of the past. Consistent with neoliberalism's emphasis on a lean state, government intervention via the provision of new social housing appeared off the agenda. Although some contestation was evident among one individual working in government/housing administration for a renewal of funding, the opinions of the respondents showed great scepticism over the materialization of such funding.

Further, with respect to the literature taken from observations of "social mix" in the international context that laments the privatization of once public goods, the information presented in the interviews here, did not parallel such concerns and criticisms. Instead, many of the respondents in the not for profit/nongovernmental sector focussed more upon the problems of concentrated poverty and the stigmas attached to $\mathrm{TCH}$ buildings. These viewpoints are consistent with literature that emphasizes "social mix" as a possible cure for such problems. Unfortunately, as mentioned earlier, missing from the dialogue often is a discussion of the impact of neoliberal reforms or the sustained neglect of social housing buildings.

Perhaps most interesting with regard to the findings of this study was the extent to which contestation against the neoliberalization of the social housing sector was not readily apparent. 
Although pessimism and scepticism were continually expressed towards the social housing sector, for the majority of respondents, such sentiments were not attached to any larger call for structural change. Perhaps counterintuitive to conceptions of grassroots activism or resistance, within this study group it was the individuals within government/housing administration who expressed: a) a desire for a greater role of government in the supply of social housing and an agenda to influence such developments, and b) concerns regarding the inclusion of different ethnocultural groups in "revitalized" communities. Those individuals who were "on the ground", working directly with tenants whom one might assume would possess the most agency and desire to change the structures of social housing, instead appeared to have accepted the existing policy climate. In the context of increasing demands, stretched budgets, and the economic downturn of the past two years, perhaps this is understandable. Nevertheless, it does not point strongly to prospects of contestation of the present social housing system. Instead, they may support an earlier finding by Hackworth $\left(2009, \mathrm{p} .{ }^{* * *}\right)$ that stressed "serious resistance must be grassroots, tenant organized and focussed and it cannot be an instrumental extension of the local housing agency". An interesting avenue for further research would be to interview tenants living in Toronto's social housing sector.

\section{Conclusion}

This paper has sought to explore the evolution and impact of changes in Toronto's social housing sector. From the research compiled here, several conclusions are apparent. First, and perhaps most significant is the change that has been witnessed in the provision of social housing. While an earlier post-war Keynesian environment recognized the need for the supply of a stock of affordable housing, a new, neoliberal inspired policy environment has induced the removal of subsidies for new social housing supply and resulting deterioration of existing stock. Within 
cities such as Toronto, that which has transpired now represents a housing crisis in which many low income earners cannot secure housing that is adequate, suitable or affordable. The implications of a housing situation that appears to segregate low income people along racial and ethnic lines is deeply troubling.

In regard to social mix ventures in TCH housing, despite the proposed benefits of "social mix", it is clear from existing literature that there is little evidence to point towards socially beneficial outcomes for those of lower incomes. Further, and perhaps most important to note is the simple fact that the initiatives themselves do nothing to increase the supply of affordable housing in the city or address the growing wait list situation. Instead, they can be interpreted as a thinly veiled attempt to gentrify existing social housing developments. Such a development is consistent with efforts to increase the city's competitive edge in global city formation and competitiveness. They do little however, to address those most in need. Although the majority of interviews in this study appear to have accepted the current agenda of the social housing sector and portray "revitalization" as at least a "necessary evil" in the Toronto context, it cannot be ignored the dismal record of "social mix" initiatives internationally and the overshadowing of the responsibilities of the state in providing housing for lower income groups. In a city such as Toronto that actively endorses the banner "diversity our strength", it is essential that social housing initiatives be re-thought and reworked in a way that addresses the problems of supply and works to ensure inclusion. 


\section{Appendix}

\section{Interview Questions*}

1. As a $<$ role $>$, what are your impressions of the housing situation in Toronto in general?

2. What do you think we need to do to solve these city wide issues?

3. What do you perceive is the role of social housing providers such as Toronto Community Housing in addressing housing issues in the City of Toronto?

4. What do you think about new efforts to revitalize specific TCH housing developments?

5. What do you perceive are the benefits of these new revitalization projects?

6. What do you perceive are the potential challenges for these new revitalization projects?

7. Do you see any potential benefits that are specific to immigrants who live/will live in these new revitalized housing developments?

8. Do you see any potential challenges that are specific to immigrants who live or will live in these new revitalized housing developments?

These interview questions were asked in conjunction with other questions for a research study by Professor Sutama Ghosh of the geography department at Ryerson. 


\section{References}

August, M. \& Walks, A. (Forthcoming). From social mix to political marginalization? The redevelopment of Toronto's public housing and the dilution of tenant organizational power. In Bridge, G., Butler, T., \& Lees, L. (Eds.). Mixed-income Communities: Gentrification by Stealth. Bristol: The Policy Press.

August, M. (2008). Social mix and Canadian public housing redevelopment: Experiences in Toronto. Canadian Joumal of Urban Research - Canadian Public Policy Supplement. $17(1) .35-73$

Bacher, J.C. (1993). Keeping to the Marketplace: The Evolution of Canadian Housing Policy. Montreal: McGill \& Queen's University Press.

Bacher, JC \& JD Hulchanski. (1987). Keeping Warm and Dry: The Policy Response to the Struggle for Shelter Among Canada's Homeless, 1900-1960. Urban History Review 16(2): $147-163$.

Bauder, H. (2002). Neighbourhood Effects and Cultural Exclusion. Urban Studies 39(1): 85-93.

Blumenberg, E. \& M. Manville. (2004). Beyond the spatial mismatch: Welfare recipients and transportation policy. Journal of Planning Literature. 19(2): 182-205.

Boudreau, J.A., Keil, R., \& D. Young. (2009). Changing Toronto: Governing Urban Neoliberalism. Toronto: University of Toronto Press.

Brenner, N. \& N. Theodore. (2002). Cities and the Geographies of "Actually Existing Neoliberalism". Antipode. 34(3): 349-379.

Brushett, K. (2007). Where Will the People Go: Toronto's Emergency Housing Program and the Limits of Canadian Social Housing Policy, 1944-1957. Journal of Urban History. 33(3): 375-399.

City of Toronto. (Online). Municipal Licensing and Standards Division - Licensed Rooming Houses and Bachelorettes- Chapter 285. Retrieved from:

http://www.toronto.ca/licensing/rooming_houses.htm

City of Toronto. (2009). Staff Report for Action on 2008 TCHC Annual Shareholder Report and Meeting. Retrieved from:

http://www.toronto.ca/legdocs/mmis/2009/ex/bgrd/backgroundfile-22984.pdf

CMHC. (2006). Research Report: Distinct Housing Needs Series: The Housing Situation and Needs of Recent Immigrants in the Montreal, Toronto, and Vancouver CMAs: An Overview. Retrieved from: 
http:/www03.cmhcchl.gc.ca/catalog/productDetail.cfm?csid=1\&cat=123\&itm=48\&lang=en\&fr $=1260849458107$

CMHC. (2009). Rental Vacancy Rate, Canada, Provinces and Metropolitan Areas, $1992-2008$ (per cent). Retrieved from:

http://www.cmhc.ca/en/corp/about/cahoob/data/data_004.cfm

Creswell, J. (2009). Research Design: Qualitative, Quantitative and Mixed Methods Approaches. Thousand Oaks, CA: Sage Publishers

Creswell, J. (2007). Qualitative Inquiry \& Research Design: Choosing Among Five Approaches. Thousand Oaks, CA: Sage Publishers

Dreier, P. \& JD Hulchanski (1993). The Role of Nonprofit Housing in Canada and the United States: Some Comparisons. Housing Policy Debate. 4(1): 43-80.

Fanelli,C. \& J. Paulson. (2010). Municipal Malaise: Neoliberal Urbanism and the Future of Our Cities. Socialist Project. Retrieved from: http://www.globalresearch.ca/index.php?context=va\&aid=19246

Florida, R. (2003) The Rise of the Creative Class. New York: Basic Books.

Fraser, J. \& Nelson, M.H. (2008). Can Mixed-Income Housing Ameliorate Concentrated Poverty? The Significance of a Geographically Informed Sense of Community. Geography Compass. 2(6): 2127-2144.

Glynn (2009). Regeneration as a Trojan Horse. In S. Glynn (ed.) Where the Other Half Lives: Lower Income Housing in a Neoliberal World. New York: Pluto Press.

Hackworth, J.\& A. Moriah. (2006). Neoliberalism, Contingency and Urban Policy: The Case of Social Housing in Ontario. International Journal of Urban and Regional Research. 30(3): $510-527$.

Hackworth, J. (2009). Political Marginalization, Misguided Nationalism and the Destruction of Canada's Social Housing Systems in S. Glynn (Ed.) Where the Other Half Lives: Lower Income Housing in a Neoliberal World. London: Pluto Press.

Harris, R. (2000) More American than the United States: Housing in Urban Canada in the Twentieth Century, Journal of Urban History. 26(4): 456-478.

Harvey, D. (2005). A Brief History of Neoliberalism. Oxford: Oxford University Press. Housing Connections. (2010). Quarterly Activity Report $2^{\text {nd }}$ Quarter 2010. 
Hulchanski, JD. (2004). How Did We Get Here? The Evolution of Canada's Exclusionary Housing System in JD Hulchanski \& M. Shapcott (Eds) Finding Room: Policy Options for a Canadian Rental Housing Strategy. Toronto: University of Toronto Press.

Hulchanski (2007). The Three Cities within Toronto: Income polarization among Toronto's neighbourhoods, 1970-2000. Centre for Urban and Community Studies. Research Bulletin \#40. Retrieved from:

http://www.urbancentre.utoronto.ca/pdfs/researchbulletins/CUCSRB41 Hulchanski Thr ee_Cities_Toronto.pdf

Joseph, M.L., Chaskin, R.J., \& Webber, H.S. (2007). The Theoretical Basis for Addressing Poverty Through Mixed Income Development. Urban Affairs Review. 42: 369-405.

Kain, J.F. (1992). The Spatial Mismatch Hypothesis: Three Decades Later. Housing Policy Debate. 3(2): $371-460$

Kipfer, S. \& R. Keil. (2002). Toronto Inc.: Planning the Competitive City in the New Toronto. Antipode. 34 (2): 227-264.

Kipfer, S. \& J. Petrunia. (2009). Recolonization and public housing: a Toronto Case Study. Studies in Political Economy. 83:111-139

Ley, D. \& J. Tutchener (2001). Immigration, Globalization and House Prices in Canada's Gateway Cities. Housing Studies. 16(2): 199-2001.

Marcuse, P. \& R. Van Kempen. (2002). Of States and Cities: The Partitioning of Urban Space. Oxford: Oxford University Press.

May, J. (2008). Social Lives in Social Housing: Resident Connections to Social Services. Canadian Policy Research Network. Research Report.

Moloney, P. (2010). Project too big, neighbours say Lawrence Heights redevelopment; Site would balloon from 1,208 units today up to 7,500 in 20 years. The Toronto Star. June 23, 2010. GT 10

Moskalyk, A. (2008) The Role of Public-Private Partnerships in Funding Social Housing in Canada. Canadian Policy Research Networks Research Report.

Murdie, R. (1994). 'Blacks in near-ghettos?' black visible minority population in metropolitan Toronto housing authority public housing units. Housing Studies. 9(4): 435-457.

Murdie, R. (1998). The welfare state, economic restructuring and immigrant flows: impacts on socio-spatial segregation in Greater Toronto. In S. Musterd \& W. Ostendorf (Eds) Urban Segregation and the Welfare State: Inequality and Exclusion in Western Cities. London: Routledge Press. 
Murdie, R.A. \& C. Teixeira.(2003). Towards a Comfortable Neighbourhood and Appropriate Housing : Immigrant Experiences in Toronto in M. Lanphier \& P. Anisef (Eds). The World in a City. Toronto: University of Toronto Press.

Murdie, R. (2004). Housing Affordibility: Immigrant and Refugee Experiences in JD Hulchanski \& M. Shapcott (Eds) Finding Room: Policy Options for a Canadian Rental Housing Strategy. Toronto: University of Toronto Press.

Neuman, W.L. (2000) Social Research Methods: Qualitative and Quantitative Approaches. Boston: Allyn \& Bacon/Pearson.

Office of the High Commissioner for Human Rights, Fact Sheet 21 'The Human Right to Adequate Housing' . Retrieved from:

http://www.ohchr.org/Documents/Publications/FactSheet21en.pdf

Papillon, M. (2002). Immigration, Diversity and Social Inclusion in Canada's Cities. Canadian Policy Research Networks. Discussion Paper F/27.

Preston, V., Murdie, R., Wedlock, J. Kwak, MJ, D'Addario, S, Logan, J., Murnaghan, AM, Agrawal, S. \& U. Anucha. (2009). At Risk in Canada's Outer Suburbs: A Pilot Study of Immigrants and Homelessness in York Region. In: Hulchanski, JD; Campsie, P; Chau, S; Hwang, S. ; Paradis, E (Eds.). Finding Home: Policy Options for Addressing Homelessness in Toronto. Toronto: Cities Centre, University of Toronto.

Purdy, S. (2004). BY THE PEOPLE, FOR THE PEOPLE Tenant Organizing in Toronto's Regent Park Housing Project in the 1960s and 1970s. Journal of Urban History. 30 (4): 519-548.

Purdy, S. \& N. Kwak. (2007). New Perspectives on Public Housing Histories in the Americas. Journal of Urban History. 33(3): 357-374.

Robinson, D. (2002). Missing the Target? Discrimination and Exclusion in the Allocation of Social Housing. In P. Sommerville \& A. Steele (Eds.). 'Race', Housing and Social Exclusion. London: Jessica Kingsiley Publishers.

Rose, D. (2004). Discourses and Experiences of Social Mix in Gentrifying Neighbourhoods: A Montreal Case Study. Canadian Journal of Urban Research. 13(2): 278-316.

Rutter,J. \& M. Latorre. (2009). Social Housing Allocation and Immigrant Communities. Equality and Human Rights Commission. United Kingdom. Retrieved from: www.equalityhumanrights.com/researchreports

Sahak, J. (2008). Race, Space and Place: Exploring Toronto's Regent Park from a Marxist Perspective. Theses and dissertations. Paper 93. http://digitalcommons.ryerson.ca/dissertations/93 
Sassen, S. (1991). The Global City: New York, London, Tokyo. Princeton New Jersey: Princeton University Press.

Schippling, R.M. (2007) Public housing redevelopment : residents' experiences with relocation from phase 1 of Toronto's Regent Park revitalization. Ann Arbor, MI: UMI Dissertation Services.

Siemiatycki, M., Rees, T., Ng, R., and R. Khan. (2003). Integrating Community Diversity in Toronto: On Whose Terms in M. Lanphier \& P. Anisef (Eds). The World in a City. Toronto: University of Toronto Press.

TCH. (Online). Investing in Buildings. Retrieved from: http://www.torontohousing.ca/revitalization

Toronto Community Housing. (2010). Community Management Plan 2010-2012. Retrieved from: http://www.torontohousing.ca/community_management_plan

Thibert, J. (2007). Inclusion and Social Housing Practice in Canadian Cities: Following the Path from Good Intentions to Sustainable Projects. Canadian Policy Research Networks.

Truelove, M. (2000). Services for immigrant women: an evaluation of locations. Canadian Geographer. 44(2): 135-151.

United Way of Toronto. (2004). Poverty by Postal Code Executive Summary. Retrieved from: http://www.unitedwaytoronto.com/downloads/whatWeDo/reports/PPC-ExecSummary-04.pdf

Walks, R.A., \& L. Bourne. (2006). Ghettos in Canada's cities? Racial segregation, ethnic enclaves and poverty concentration in Canadian urban areas. The Canadian Geographer. 50(3): 273-297. 